\title{
Autosomal hypophosphataemic bone disease responds to $1,25-(\mathrm{OH})_{2} \mathrm{D}_{3}$
}

\author{
CHARLES R SCRIVER, TERRY READE, FAHED HALAL, TERESA COSTA, \\ AND DAVID E C COLE \\ Medical Research Council Genetics Group, Department of Paediatrics, \\ Department of Biology, and Human Genetics Centre, McGill University, Montreal, Quebec, Canada
}

SUMmARY We diagnosed non X-linked hypophosphataemic bone disease in a 38-month-old girl. Findings included: genu varum, shortened stature, fasting hypophosphataemia $(2 \cdot 3-2 \cdot 5 \mathrm{mg} / 100 \mathrm{ml}$; $0 \cdot 74-0.81 \mathrm{mmol} / \mathrm{l})$, diminished theoretical renal threshold for phosphate (TmP/GFR), and osteomalacia without rickets. One parent (the father) had fasting hypophosphataemia $(2 \cdot 3-2 \cdot 7 \mathrm{mg} / 100$ $\mathrm{ml} ; 0.74-0.87 \mathrm{mmol} / \mathrm{l}$ ) and low TmP/GFR without osteomalacia or shortened stature. Treatment of the girl with $1,25-(\mathrm{OH})_{2} \mathrm{D}_{3}(1 \mu \mathrm{g}$ a day) raised the level of serum phosphorus, improved tubular reabsorption of phosphate, and healed the bone deformity; this combination of responses is not present in X-linked hypophosphataemia. There was no correction of hypophosphataemia or TmP/ GFR with $1,25-(\mathrm{OH})_{2} \mathrm{D}_{3}$ treatment (1-3 $\mu \mathrm{g}$ a day) in the father.

Hypophosphataemic bone disease (HBD) ${ }^{1}$ is an inherited disorder of phosphate homeostasis. Although the condition is in some ways analogous to X-linked hypophosphataemia (XLH), ${ }^{2}$ there are important differences between the two diseases. HBD is an autosomal disorder, dominant in its inheritance when not sporadic whereas XLH, also dominantly inherited, is the product of mutation at a locus on the X-chromosome. While in both conditions there is osteomalacia of endosteal trabecular bone, only in XLH is florid rickets present, affecting the epiphyses and compromising linear growth. In both diseases there is a reduced theoretical renal threshold for phosphate (TmP/ GFR) and an impaired maximum tubular reabsorption activity for phosphate (TmP). Fractional renal excretion of filtered phosphate is normal in the fasting hypophosphataemic state in HBD, whereas it is greatly increased at the equivalent serum phosphate level in XLH: and while residual phosphate reabsorption activity is readily inhibited by parathyroid hormone in HBD, it is insensitive to the hormone in XLH. Thus, HBD differs from XLH, both in bone metabolism and in renal handling of phosphate, despite comparable hypophosphataemia in each. The most simple explanation for the different phenotypes is that independent gene products, each responsible for a different aspect of phosphate homeostasis, are affected by the two mutations. ${ }^{1}$
We describe the youngest patient with HBD yet diagnosed at our hospital. Penetrance of the mutant gene in the patient was clearly different from that in her less affected father. We studied the effect of the vitamin $D$ analogue $1,25-(\mathrm{OH})_{2} \mathrm{D}_{3}$ on the HBD phenotype in the patient, and observed that treatment was accompanied by a clear increase in serum phosphorus to normal, with improved tubular reabsorption of the phosphate anion and a fall in plasma alkaline phosphatase activity with bone healing. The father showed no response to 1,25$(\mathrm{OH})_{2} \mathrm{D}_{3}$.

\section{Case report}

This 38-month-old girl was referred to us with an 18-month history of genu varum. The perinatal history and postnatal nutrition had been normal. She first walked at $\mathbf{1 0}$ months. Clinical examination

Abbreviations:

TmP/GFR: theoretical renal phosphate threshold

HBD: hypophosphataemic bone disease

XLH: X-linked hypophosphataemia

TmP: maximum tubular reabsorption activity for phosphate

TRP: tubular resorption of phosphate 
showed long-bone deformities confined to the lower limbs; the intercondyle distance was $12 \mathrm{~cm}$. There were no clinical signs of rickets and dental development was normal. Her weight was at the 10th centile, and standing height just below the 3rd (Stuart-Meredith growth charts). Intestinal malabsorption was excluded on clinical evidence and by the appropriate laboratory investigations and so, too, were hepatic and renal disease. Roentgen-ray examination showed no rachitic bone changes; however, there was coarsened trabeculation in metaphyses and diaphyses of long bones and sclerosis in the distal medial metaphyses of both femora, as reported in previous patients. ${ }^{1}$ Additional investigation showed: serum total calcium $9.5 \mathrm{mg} / 100 \mathrm{ml}$ $(2.4 \mathrm{mmol} / \mathrm{l})$, serum phosphorus $2.5 \mathrm{mg} / 100 \mathrm{ml}$ $(0.81 \mathrm{mmol} / \mathrm{l})$, serum alkaline phosphatase $221 \mathrm{SIU}$. Urine contained an increased amount of glycine (discerned by 2-dimensional partition chromatography of amino-acids). ${ }^{3}$ A similar finding in each parent implied that the daughter was probably a heterozygote for the mutation causing renal iminoglycinuria, a benign inborn error of amino-acid transport. ${ }^{4}$

Special investigations. Additional studies in the patient showed: normal serum level of immunoreactive parathyroid hormone (measured in the laboratory of FH Glorieux using a modified Cterminal antiserum for radioimmune assay by the method of Arnaud et al. $) ;{ }^{5}$ normal serum level of $1,25-(\mathrm{OH})_{2} \mathrm{D}_{3} 39 \mathrm{ng} / \mathrm{ml}(93.6 \mathrm{nmol} / \mathrm{l})$ (normal, $39 \pm 10 \mathrm{ng} / \mathrm{ml}$, mean $\pm \mathrm{SD}$ ), measured in the laboratory of $\mathrm{H} F$ De Luca by the method of Eisman et al. ${ }^{6}$

Family studies. Fasting serum samples were obtained from both parents and from a $4 \frac{1}{2}$-year-old brother, and levels of serum calcium, phosphorus, and alkaline phosphatase were measured. Linear height and body weight were measured too. The results (Table 1) showed that the father had hypophosphataemia, his average fasting serum phosphorus concentration being below the $99 \%$ confidence limit for age-specific normal values in males. ${ }^{7}$ The mother and brother were normal. Stature and body proportions of the father were normal and no abnormality of bone mineralisation could be detected by roentgen-ray examination. Trephine biopsy of his right iliac crest showed normal endosteal trabecular morphology bone despite his chronic hypophosphataemia.*

Renal handling of phosphate. Tubular reabsorption of phosphate (TRP) and TmP/GFR were estimated in the patient and in her father and mother at a time when their daily dietary intakes of phosphorus and calcium were normal and constant. TRP was measured by methods described previously, ${ }^{1} \mathrm{TmP} / \mathrm{GFR}$ from the nomogram of Walton and Bijvoet. ${ }^{8}$

Absolute TRP ( $\mu$ atom/100 ml GF) was below normal in both hypophosphataemic subjects (Fig. 1 and Table 2) as, in both the girl and her father, the filtered phosphate was below the normal range. However, the average fractional reabsorption (expressed as \% TRP) was normal (Table 2). TmP/ GFR, in the patient, was below the range of values characteristic in children; the father had a low normal value. The mother, who did not have hypophosphataemia, had normal renal handling of phosphate.

The tubular response to a rapid intravenous infusion of parathyroid gland extract (Para-thormone Lilly) was studied by the method reported previously. ${ }^{9}$ Urinary cyclic-AMP excretion increased 10-fold from a normal baseline $(8.35 \mathrm{nmol} / \mathrm{mg}$ creatinine $)$ in the initial 30-minute period after the parathyroid gland infusion; this response is within the normal range. ${ }^{10}$ At the same time fractional excretion of phosphate increased 4.7-fold; this response is quite different from the blunted phosphate excretion response characteristic of $\mathrm{XLH}^{9}$ and probably is greater than the normal response (D E C Cole and C R Scriver, unpublished data).

*Biopsy was carried out by P Marie and F H Glorieux, Shriners Hospital, Montreal.

Table 1 Clinical data for members in $H B D$ family

\begin{tabular}{|c|c|c|c|c|c|c|c|c|}
\hline \multirow[t]{2}{*}{ Subject } & \multirow[t]{2}{*}{ Age (years) } & \multicolumn{2}{|c|}{ Height } & \multicolumn{2}{|c|}{ Weight } & \multicolumn{3}{|l|}{ Serum } \\
\hline & & $\mathrm{cm}$ & Centile & $k g$ & Centile & $\begin{array}{l}\text { Phosphorus } \\
(\mathrm{mg} / 100 \mathrm{ml})\end{array}$ & $\begin{array}{l}\text { Calcium } \\
(\mathrm{mg} / 100 \mathrm{ml})\end{array}$ & $\begin{array}{l}\text { Alkaline } \\
\text { phosphatase (SIU) }\end{array}$ \\
\hline $\begin{array}{l}\text { Father } \\
\text { Mother } \\
\text { Son } \\
\text { Daughter }\end{array}$ & $\begin{array}{c}37 \\
30 \\
4 \frac{1}{2} \\
3 \frac{1}{2}\end{array}$ & $\begin{array}{c}174^{*} \\
165 \\
112 \\
90.5\end{array}$ & $\begin{array}{r}50 \text { th } \\
50 \text { th } \\
90 \text { th } \\
<3 \text { rd } \dagger\end{array}$ & $\begin{array}{l}90 \\
59 \cdot 4 \\
21 \cdot 6 \\
13 \cdot 1\end{array}$ & $\begin{array}{r}>97 \text { th } \\
25 \text { th } \\
90 \text { th } \\
10 \text { th }\end{array}$ & $\begin{array}{l}2 \cdot 2-2 \cdot 7 \dagger \\
3 \cdot 3 \\
4 \cdot 5 \\
2 \cdot 3-2 \cdot 5 \dagger\end{array}$ & $\begin{array}{l}9 \cdot 0-9 \cdot 3 \\
9 \cdot 3 \\
9 \cdot 7 \\
9 \cdot 4\end{array}$ & $\begin{array}{c}34-40 \\
33 \\
99 \\
140-221\end{array}$ \\
\hline
\end{tabular}

Lower $99 \%$ confidence limits on normal values for fasting serum inorganic phosphorus in 3 -year-old child $\simeq 3 \cdot 75 \mathrm{mg} / 100 \mathrm{ml}(1 \cdot 2 \mathrm{mmol} / 1)$ and in 37 -year-old $\operatorname{man} \simeq 2.7 \mathrm{mg} / 100 \mathrm{ml}(0.87 \mathrm{mmol} / \mathrm{l}) .7$

*Height appropriate for weight and familial phenotype.

Father and daughter are carriers of mutant gene on the basis of relevant data. $\dagger$ 
Table 2 Renal handling of inorganic phosphate in $H B D$ family before and during treatment with $1,25-(\mathrm{OH})_{2} \mathrm{D}_{3}$

\begin{tabular}{|c|c|c|c|c|c|c|c|}
\hline \multirow[t]{2}{*}{ Subject } & \multirow[t]{2}{*}{ Date } & \multirow{2}{*}{$\begin{array}{l}1,25-(\mathrm{OH})_{2} D_{3} \\
(\mu \mathrm{g} / \text { day })\end{array}$} & \multirow{2}{*}{$\begin{array}{l}\text { Phosphorus } \\
\text { (mg/100 ml) }\end{array}$} & \multicolumn{2}{|l|}{$T R P \dagger$} & \multirow{2}{*}{$\begin{array}{l}\text { TmP/GFR } \\
(\mathrm{mg} / 100 \mathrm{ml})\end{array}$} & \multirow{2}{*}{$\begin{array}{l}\text { Creatinine } \\
\text { clearance } \\
(m l / \text { min per } 1.73 \\
\left.m^{2}\right)\end{array}$} \\
\hline & & & & 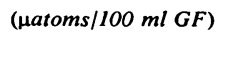 & $(\%)$ & & \\
\hline Daughter & $\begin{array}{c}17 \text { January } 1978 \\
3 \text { March } 1978 \\
8 \text { March } 1978 \\
27 \text { June } 1978 \\
8 \text { March } 1979\end{array}$ & $\begin{array}{l}1 \cdot 0,2 \text { days } \\
1 \cdot 0,3 \text { months } \\
0 \cdot 5-1 \cdot 0,8 \text { months } \\
0 \cdot 5,1 \text { month }\end{array}$ & $\begin{array}{l}2 \cdot 5 \\
2 \cdot 3 \\
2 \cdot 9 \\
3 \cdot 3 \\
2 \cdot 9\end{array}$ & $\begin{array}{l}59 \\
59 \\
83 \\
96 \\
83\end{array}$ & $\begin{array}{l}73 \\
79 \\
89 \\
91 \\
89\end{array}$ & $\begin{array}{l}1.85 \\
1.85 \\
2.75 \\
3.50 \\
2.80\end{array}$ & $\begin{array}{r}55 \\
103 \\
101 \\
71 \\
92\end{array}$ \\
\hline Father $\dagger$ & $\begin{array}{l}28 \text { April } 1979 \\
15 \text { February } 1978 \\
23 \text { August } 1978 \\
14 \text { May } 1979\end{array}$ & $\begin{array}{l}0 \cdot 75,2 \text { weeks } \\
1 \cdot 0,4 \text { months }\end{array}$ & $\begin{array}{l}3 \cdot 3 \\
2 \cdot 7 \\
2 \cdot 1 \\
2 \cdot 4 \\
3 \cdot 3\end{array}$ & $\begin{array}{l}95 \\
74 \\
51 \\
64 \\
91\end{array}$ & $\begin{array}{l}89 \\
86 \\
74 \\
83 \\
86\end{array}$ & $\begin{array}{l}3.20 \\
2.45 \\
1.65 \\
2.05 \\
2.95\end{array}$ & $\begin{array}{r}100 \\
68 \\
103 \\
151 \\
90\end{array}$ \\
\hline
\end{tabular}

Serum phosphorus representing inorganic phosphate anion; TRP $=$ tubular reabsorption of phosphate; $\mathrm{TmP} / \mathrm{GFR}=$ theoretical renal phosphate threshold.

†Average of 3 consecutive fasting clearance periods, as described by Scriver et al. ${ }^{1}$

$\ddagger$ Derived from nomogram of Walton and Bijvoet $;^{8}$ normal values for adult $2 \cdot 3-4 \cdot 4 \mathrm{mg} / 100 \mathrm{ml}$; values for children are higher but not specified.

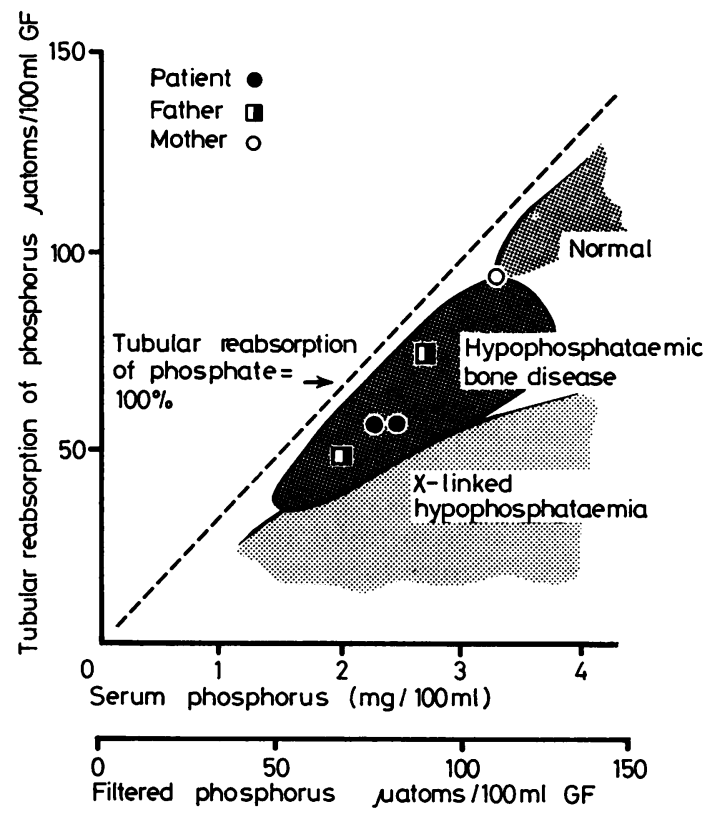

Fig. 1 Relationship between tubular reabsorption of phosphorus and serum level (or filtered load) in members of an HBD family: patient and father were hypophosphataemic and could be classified as $H B D$ subjects; the mother was normal. Range of findings in other $H B D$ patients is indicated (taken from Scriver et al). ${ }^{1}$ Distribution of findings in male $X L H$ subjects is shown for comparison (taken from Glorieux and Scriver). ${ }^{9}$

Response to $1,25-(\mathrm{OH})_{2} \mathbf{D}_{3}$. The patient and her father were each given $1,25-(\mathrm{OH})_{2} \mathrm{D}_{3}$ (Rocaltrol, Hoffman-LaRoche, Canada), 0.75-3.0 $\mu$ g daily by mouth for various lengths of time (Figs 2 and 3 ). Serum phosphorus rose rapidly to higher and usually normal levels in the patient during treatment with

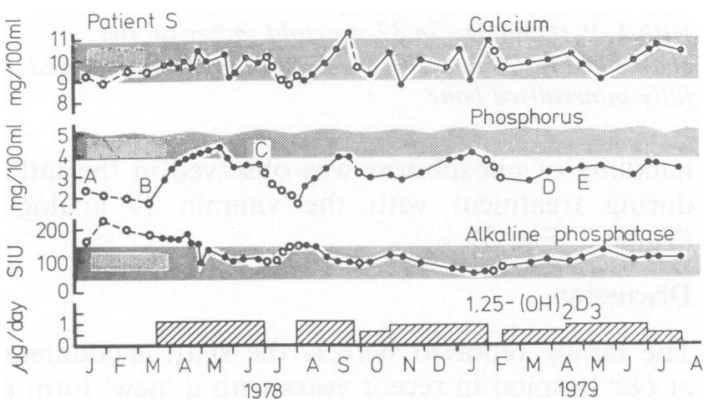

Fig. 2 Progress graphs for serum calcium, phosphorus, and alkaline phosphatase in a female $H B D$ patient (born September 1974) before and during treatment with $1,25-(\mathrm{OH})_{2} D_{3}$. Letters $\mathrm{A}-\mathrm{E}$ indicate times when renal handling of phosphorus was measured (Table 2). Linear growth rate accelerated, leg bowing diminished, and condition of bone lesions improved during course of treatment.

$1,25-(\mathrm{OH})_{2} \mathrm{D}_{3}$ (Table 2, Fig. 2); values for TRP, $\%$ TRP, and TmP/GFR increased too. Changes in her serum phosphorus level occurred primarily in association with changes in dosage of $1,25-(\mathrm{OH})_{2} \mathrm{D}_{3}$; there would be a rise after the dosage had been increased and a fall after the drug had been reduced or stopped (Fig. 2). On one occasion during the first cycle of treatment serum phosphorus fell spontaneously to below the normal range, without change in dosage.

Height increased to the 3 rd centile in the patient and height velocity changed from the 50th to the 90th centile (Tanner chart). Roentgen-ray studies indicated steady improvement of bone mineralisation, but bone biopsies were not performed. The genu varum deformity healed after 12 months of treatment with $1,25-(\mathrm{OH})_{2} \mathrm{D}_{3}$.

No consistent change in serum level or renal 


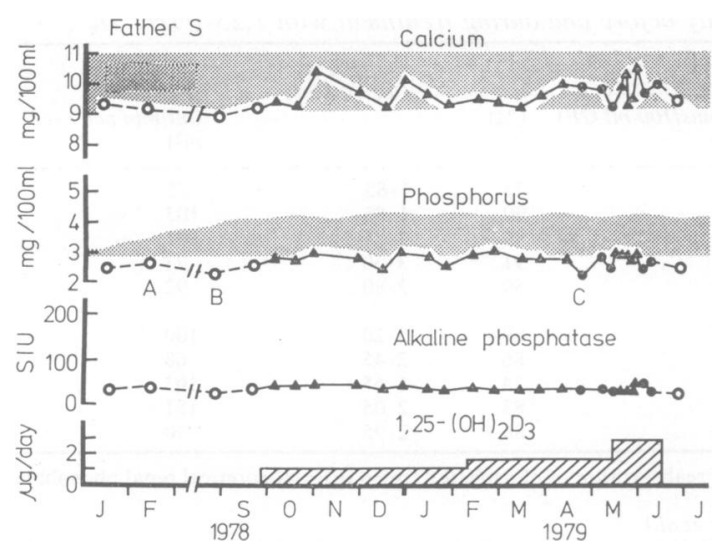

Fig. 3 Progress graphs for serum calcium, phosphorus, and alkaline phosphatase, before and during treatment with $1,25(\mathrm{OH})_{2} D_{3}$, in 37-year-old father of girl, shown in Fig. 2. Bone biopsy before treatment showed fully mineralised bone.

handling of phosphorus was observed in the father during treatment with the vitamin $D$ analogue (Table 2, Fig. 3).

\section{Discussion}

The family reported here is the sixth encountered at our hospital in recent years with a 'new' form of non X-linked HBD. The patients from the previous five families ${ }^{1}$ were identified when investigation of the various forms of hypophosphataemia had eliminated other diagnoses. The new patient was tentatively diagnosed as suffering from HBD on first referral from the following evidence: (1) striking, persistent hypophosphataemia without evidence of a parathyroid hormone-mediated or calcipenic form of hypophosphataemia; ${ }^{11}$ (2) absence of rickets, yet with evidence of osteomalacia in long bones, an important feature which distinguishes this condition from any other autosomal form of hypophosphataemia with rickets; ${ }^{12}$ (3) genu varum as the presenting sign in late infancy; (4) normal \% TRP in the fasting state and an adequate phosphaturic response to parathyroid hormone; (5) one hypophosphataemic parent indicating autosomal inheritance.

We are confident that our patient has a Mendelian form of hypophosphataemia that is not XLH. The reason for our confidence in this diagnosis is that the HBD and XLH phenotypes are different; in our experience the HBD phenotype is consistently expressed in children, and our patient resembles others; father-to-son transmission of the HBD phenotype has been observed, thus eliminating $\mathrm{X}$-linkage of the HBD gene.
New findings in HBD, since the original description, and gained largely from the present study, are: (1) normal serum $1,25-(\mathrm{OH})_{2} \mathrm{D}_{3}$ levels in this and in other HBD patients; ${ }^{13}(2)$ a rise in the serum level of phosphorus related to enhanced renal reabsorption after treatment with $1,25-(\mathrm{OH})_{2} \mathrm{D}_{3}$; (3) improved bone mineralisation during prolonged treatment with $1,25-(\mathrm{OH})_{2} \mathrm{D}_{3}$; (4) no reduction of hypophosphataemia in the adult with HBD with $1,25-(\mathrm{OH})_{2} \mathrm{D}_{3}$ treatment; (5) and normal mineralisation of endosteal trabecular bone in an adult with persistent hypophosphataemia.

The investigation also provided useful information for the clinician: it showed that HBD in childhood could be successfully treated with $1,25-(\mathrm{OH})_{2} \mathrm{D}_{3}$. In XLH, the other main form of 'phosphopenic' bone disease in childhood, ${ }^{11}$ the hypophosphopenia responds poorly to $1,25-(\mathrm{OH})_{2} \mathrm{D}_{3}$ in older patients ${ }^{14-15}$ and modestly in children under longterm treatment, it is not associated with any change in TmP/GFR ( $T$ Costa, $T$ M Reade, D E C Cole, and $\mathrm{C} \mathrm{R}$ Scriver, unpublished data). However, treatment with the drug in combination with phosphate replacement greatly improves bone mineralisation in XLH (F H Glorieux, personal communication; T Costa et al., 1980, unpublished data). Thus, the clinical management and prevention of limb deformity in HBD should be a fairly simple matter in the future, provided there is careful supervision of the patient to prevent hypercalcaemia (Fig. 2).

Different mechanisms for tubular reabsorption of phosphate anion seem to be affected in XLH and HBD. ${ }^{1}$ Evidence from these two diseases indicates that the human nephron may possess one mechanism, more sensitive to inhibition by parathyroid hormone, which is under the control of an X-linked gene, and another less sensitive to parathyroid hormone which is under the control of an autosomal gene. Recent studies ${ }^{16-19}$ in the Hyp mouse homologue of human XLH are compatible with this hypothesis. If such is the case, it implies that the $X$-linked system-intact in HBD patients-may be responsive to $1,25-(\mathrm{OH})_{2} \mathrm{D}_{3}$. The response to treatment with $1,25-(\mathrm{OH})_{2} \mathrm{D}_{3}$ in $\mathrm{HBD}$ is none the less puzzling, and occurs despite pretreatment serum levels of the analogue being in the normal range. This finding implies a pharmacological effect with treatment rather than replacement of a deficient physiological component controlling phosphate homeostasis.

Treatment with $1,25-(\mathrm{OH})_{2} \mathrm{D}_{3}$ had the expected effect $^{20}$ on calcium homeostasis in HBD (Figs 2 and 3). This finding suggests that the response in phosphate homeostasis could be linked to calcium absorption in the intestine and to an associated 
enhancement of phosphate absorption in the presence of calcium ion..$^{14}$ However, serum phosphorus and renal handling of phosphate improved only in the child with HBD who would normally have a higher TmP/GFR than her non-responding parent. This finding suggests that $1,25-(\mathrm{OH})_{2} \mathrm{D}_{3}$ may act on the cellular target of the sex hormones which lower TmP/GFR in the adolescent and adult, and may have its effect only when these hormones are quiescent.

The other important difference observed between the HBD patient and her hypophosphataemic parent concerned bone mineralisation; this was deficient in the patient and normal in the parent. Perhaps, progressive repair of bone in HBD during treatment with $1,25-(\mathrm{OH})_{2} \mathrm{D}_{3}$ is a signal to the nephron to alter TmP/GFR. What the signal might be is unknown; subsequent observations in HBD patients will be of interest. The lack of response to $1,25-(\mathrm{OH})_{2} \mathrm{D}_{3}$ in our patient's parent could be doserelated but this is unlikely in view of the response in serum calcium to the doses used.

We are grateful to Dr F H Glorieux, Dr P Marie, and Rose Travers, Genetics Unit, Shriners Hospital, Montreal, for the bone biopsy, to Dr A Hamstra and Dr F H DeLuca, Department of Biochemistry, Faculty of Agriculture, University of Wisconsin, for measuring the serum $1,25-(\mathrm{OH})_{2} \mathrm{D}_{3}$, to Anne Rowlands for the urinary cyclic-AMP measurements, and to Dr B Nogrady for interpreting the $x$-rays. Dr $P$ LeMorvan of Hoffman-LaRoche Limited, Canada, kindly supplied us with $1,25-(\mathrm{OH})_{2} \mathrm{D}_{3}$ (Rocaltrol).

Dr Halal was a United Services Club Council Telethon Fellow of the McGill University-Montreal Children's Hospital Research Institute, and Dr Costa and Dr Cole held MRC (Canada) Fellowships.

This study was supported by the Quebec Network of Genetic Medicine and MRC, Canada.

\section{References}

1 Scriver C R, MacDonald W, Reade T, Glorieux F H, Nogrady B. Hypophosphatemic nonrachitic bone disease: an entity distinct from X-linked hypophosphatemia in the renal defect, bone involvement, and inheritance. Am J Med Genet 1977; 1: 101-17.

2 Rasmussen H, Anast C. Familial hypophosphatemic (vitamin D-resistant) rickets and vitamin D-dependent rickets. In: Stanbury J B, Wyngaarden J B, Fredrickson D S, eds. The metabolic basis of inherited disease, fourth edition. New York: McGraw-Hill, 1978; 1537-62.

3 Dent C E. A study of the behaviour of some sixty amino acids and other ninhydrin reacting substances on phenol'collidine' filter paper chromatograms with notes as to the occurrence of some of them in biological fluids. Biochem $J$ 1948; 43: 169-80.
4 Scriver C R. Familial iminoglycinuria. In: Stanbury J B, Wyngaarden J B, Fredrickson D S, eds. The metabolic basis of inherited disease, fourth edition. New York: McGraw-Hill, 1978; 1593-606.

5 Arnaud C, Tsao H S, Littledike T. Radioimmunossaay of human parathyroid hormone in serum. $J$ Clin Invest $1971 ; 50: 21-34$.

- Eisman J A, Hamstra A J, Kream B E, DeLuca H F. A sensitive, precise, and convenient method for determination of 1,25 dihydroxyvitamin $D$ in human plasma. Arch Biochem Biophys 1976; 176: 235-43.

7 Greenberg G B, Winters R W, Graham J B. The normal range of serum inorganic phosphorus and its utility as a discriminant in the diagnosis of congenital hypophosphatemia. J Clin Endocrinol Metab 1960; 20 : 364-79.

8 Walton R J, Bijvoet O L M. Nomogram for derivation of renal threshold phosphate concentration. Lancet 1975; ii: 309-10.

- Glorieux F, Scriver C R. Loss of a parathyroid hormonesensitive component of phosphate transport in X-linked hypophosphatemia. Science 1972; 175: 997-1000.

10 Tucci J R, Perlstein R S, Kopp L E. The urine cyclic AMP response to parathyroid extract (PTE) administration in normal subjects and patients with parathyroid dysfunction. Metabolism 1979; 28: 814-9.

11 Scriver C R. Rickets and the pathogenesis of impaired tubular transport of phosphate and other solutes. $\mathrm{Am} \mathrm{J}$ Med 1974; 57: 43-9.

12 Harrison H E, Harrison H C. Disorders of calcium and phosphate metabolism in childhood and adolescence. Philadelphia: Saunders, 1979; 280-8.

13 Scriver C R, Reade T M, DeLuca H F, Hamstra A J. Serum 1,25-dihydroxyvitamin $D$ levels in normal subjects and in patients with hereditary rickets or bone disease. $N$ Engl J Med 1978; 299: 976-80.

14 Glorieux F H, Scriver C R, Holick M F, DeLuca H F. $\mathrm{X}$-linked hypophosphatemic rickets. Inadequate therapeutic response to 1,25 -dihydroxycholecalciferol. Lancet 1973; ii: 287-9.

15 Brickman A S, Coburn J W, Kurokawa K, Bethune J E, Harrison H E, Norman A W. Actions of 1,25-dihydroxycholecalciferol in patients with hypophosphatemic vitamin D-resistant rickets. $N$ Engl J Med 1973; 289: 495-8.

${ }_{16}$ Eicher E M, Southard J L, Scriver C R, Glorieux F H. Hypophosphatemia: mouse model for human familial hypophosphatemic (vitamin D-resistant) rickets. Proc Natl Acad Sci USA 1976; 73: 4667-71.

17 Cowgill L D, Goldfarb S, Goldberg M, Slatopolsky E, Agus Z S. Demonstration of an intrinsic renal tubular defect in mice with genetic hypophosphatemic rickets. J Clin Invest 1979; 63: 1203-10.

18 Tenenhouse H S, Scriver C R. Renal adaptation to phosphate deprivation in the Hyp mouse with X-linked hypophosphatemia. Can J Biochem 1979; 57: 938-44.

19 Tenenhouse H S, Scriver C R. The defect in transcellular transport of phosphate in the nephron is located in brush-border membranes in X-linked hypophosphatemia (Hyp mouse model). Can J Biochem 1978; 56: 640-6.

20 DeLuca H F. The vitamin D system in the regulation of calcium and phosphorus metabolism. Nutr Rev 1979; 37: 161-93.

Correspondence to Dr C R Scriver, De Belle Laboratory for Biochemical Genetics, McGill UniversityMontreal Children's Hospital Research Institute, 2300 Tupper Street, Montreal, Quebec, Canada $\mathrm{H} 3 \mathrm{H} 1 \mathrm{P3}$.

Received 22 January 1980 